\title{
Traumatic Atlantoaxial Rotatory Subluxation in Adult: Case Report
}

\section{Subluxação rotatória atlantoaxial traumática em adulto: Relato de caso}

\author{
Rafaela Campos Alcântara1( ${ }^{10}$ Jacks Alan Tenório de Souza ${ }^{2(1)}$ Andrei Fernandes Joaquim ${ }^{3(0)}$ \\ ${ }^{1}$ Universidade Federal de Alagoas, Arapiraca, AL, Brazil \\ 2 Hospital de Emergência Dr. Daniel Houly, Arapiraca, AL, Brazil \\ ${ }^{3}$ Department of Neurology, Universidade de Campinas (UNICAMP), \\ Campinas, SP, Brazil \\ Address for correspondence Rafaela Campos Alcântara, School of \\ Medicine, Avenida Manoel Severino Barbosa, Bom Sucesso (Complexo \\ de Ciências Médicas - UFAL), Arapiraca, Al, Brazil (e-mail: rafaela. \\ alcantara@arapiraca.ufal.br).
}

Arq Bras Neurocir 2021;40(1):101-106.

\section{Abstract \\ Keywords \\ - atlantoaxial rotatory subluxation \\ - trauma \\ - adult}

\section{Resumo}

\section{Palavras-Chave}

- subluxação rotatória atlantoaxial

- trauma

- adulto
Traumatic atlantoaxial rotatory subluxation (AARS) is generally found in pediatric patients, rarely found in adults, being a life-threatening condition especially when early diagnosis is not possible, which can lead to severe late neurological deficits. We describe a 38-year-old patient, victim of physical aggression caused by strangulation attempt who developed AARS, an uncommon traumatic cause. During the hospital care, the early diagnosis allowed us to institute a conservative treatment, which made the case uncommon, since most of the time surgical treatment is imperative. With the patient awake and under analgesia, a closed reduction was performed that promoted immediate pain relief, followed by a prescription of wearing a Philadelphia-type collar for 8 weeks. During the follow-up, cervical spine radiographies demonstrated no subluxation after removing the cervical collar. The patient was asymptomatic after 6 months of treatment. This case supports the importance of nonoperative management of AARS in selected cases.

A subluxação rotatória atlantoaxial (SRAA) é geralmente encontrada em pacientes pediátricos, sendo em adultos uma condição muito rara, ameaçadora à vida e que, quando não diagnosticada precocemente, pode levar a grave deterioração neurológica tardia. Descrevemos um caso de uma paciente de 38 anos, vítima de agressão física por tentativa de estrangulamento que desenvolveu uma SRAA, uma causa traumática incomum. No atendimento hospitalar, o diagnóstico precoce permitiu que o tratamento conservador fosse instituído, o que tornou o caso incomum, uma vez que, na maioria das vezes, o tratamento cirúrgico é imperativo. Com a paciente acordada e sob analgesia, foi realizada uma redução fechada que promoveu alívio imediato da dor, com prescrição de uso de colar tipo Philadelphia por 8 semanas. No seguimento, radiografias da coluna cervical não evidenciaram luxação após a retirada do colar, com manutenção da estabilidade. Em acompanhamento ambulatorial, a paciente permaneceu sem sintomas após 6 meses de seguimento. Este caso demonstra o sucesso do tratamento não cirúrgico em SRAA em adultos, que pode ser empregado em casos selecionados. received

May 25, 2020

accepted

September 4, 2020

published online

November 26, 2020
DOI https://doi.org/ 10.1055/s-0040-1719007. ISSN 0103-5355. (c) 2020. Sociedade Brasileira de Neurocirurgia. All rights reserved. This is an open access article published by Thieme under the terms of the Creative Commons Attribution-NonDerivative-NonCommercial-License, permitting copying and reproduction so long as the original work is given appropriate credit. Contents may not be used for commercial purposes, or adapted, remixed, transformed or built upon. (https://creativecommons.org/ licenses/by-nc-nd/4.0/)

Thieme Revinter Publicações Ltda., Rua do Matoso 170, Rio de Janeiro, RJ, CEP 20270-135, Brazil 


\section{Introduction}

The atlantoaxial joint comprehends the two first cervical vertebrae, also called atlas and axis, which are the central spot that supports the movements, mainly the rotation, in the craniovertebral junction ${ }^{1}$ area.

Atlantoaxial rotatory subluxation (AARS) in adults is a rare condition that, if not treated, might threaten the life of the patient. It commonly occurs in children between 0 and 18 months old and can usually be observed in a C1-C2 preexistent instability context, such as rheumatoid arthritis, Down syndrome and a variety of congenital cervical abnormalities. ${ }^{2}$

Cervical spine trauma is a common occurrence, comprehending nearly $2.4 \%$ of patients who are systemic trauma victims. These injuries vary regarding their gravity and affected structures as they can present themselves exclusively with muscle pain, or even subluxation, luxation and serious fractures. ${ }^{3}$

In this context, traumatic AARS is hardly documented in adults and, for that reason, not many cases could be found in the current literature. ${ }^{4}$ It possibly presents itself through cervicalgia (neck pain), headache and neck stiffness, usually with no neurologic deficit. In addition to that, an ipsilateral head inclination, with a chin rotation toward the opposite side of the affected area (also known as "cock-robin" posture)

4 is observed. The treatment is personalized and can be conservative, done with a simple manual traction, or a surgery with fixation for more serious cases.

In the present article, we describe a rare AARS case in a young adult patient, victim of physical aggression caused by strangulation attempt, in which success was obtained through conservative treatment. We would like to point out that the early diagnosis and the correct approach are of primary importance to achieve the best prognosis and evolution of the patient.

\section{Case Report}

Patient, female gender, 38 years old, victim of physical aggression caused by strangulation attempt, was admitted in the trauma hospital complaining of intense cervical pain, presenting (during the physical exam) neck lateral flexion to the right, head rotation to the left with a discrete flexion, expressing pain while having her cervical muscle pressed, with no neurologic deficit. A cervical spine computed tomography (CT) scan was requested and an atlantoaxial subluxation type I (Fielding and Hawkins classification) was detected, with $\mathrm{C} 1$ right lateral mass anteriorly dislocated in relation to the $\mathrm{C} 2$ superior articulation (-Fig. 1). As an approach, the patient was kept awake and under anesthesia, and a submental traction, extension and contralateral rotation were chosen. The reduction was successfully achieved, presenting an immediate pain relief (-Fig. 2). The patient was released on the next day, with no symptoms and wearing a Philadelphia collar (which she was instructed to keep for 8 weeks). Her cervical spine radiography did not present any evidence of dislocation after the removal of the Philadelphia collar. During the outpatient follow-up, she did not present any new symptoms after 6 months of treatment.

\section{Discussion}

Atlantoaxial rotatory subluxation is a rotation deformity caused by the joint dislocation, partial and reducible, including the atlas and the axis. Even being a rare condition, it is life threatening, since it can possibly compromise the vascular structures (vertebral artery) and the nervous structures (upper cervical medulla). ${ }^{5}$

The craniovertebral junction presents a complex organization of bones and articulations structures, including the first and the second cervical vertebrae, and the occipital bone. ${ }^{6}$ The atlas is the only vertebra that does not have a body and is not associated to an intervertebral disc: it has a ring format with bilaterally paired lateral mass, united by an anterior and a posterior bow. Its anterior bow has an articular surface for the axis odontoid process, forming the atlantoaxial articulation. Its lateral mass articulates with the occiput condyles in its superior part and with the C2 in its inferior part, forming the atlanto-occipital and atlantoaxial joints, respectively. The atlantoaxial joint is the main responsible for the axial rotation, somehow contributing with the flexion and extension movements. The superior aspect of the $\mathrm{C} 1$ lateral mass contains a groove that allows the vertebral artery passage before entering the foramen magnum. This mass might be compromised in cases of AARS with excessive rotation, mainly if combined with anterior dislocation. ${ }^{1,5}$

Epidemiologically, AARS is more commonly found in children, especially if an underlying disorder with ligament laxity is presented. However, AARS induced by trauma in adult patients is an extremely rare condition, as there are not many registers in the scientific literature. Its rareness is the main cause of many neglected cases registered and late diagnosis. Even so, these are the cases where there is a higher probability of more serious presentation and, sometimes, fatal ones, as the trauma mechanism is related to highenergy impact. 4

Patients with AARS might present as clinic symptomatology: cervicalgia, neck movements limitation and the typical "cock-robin" posture, when the neck is bent to a side, rotated toward the contralateral side and in discrete flexion. ${ }^{4}$ The sternocleidomastoid muscle spasm evaluation can distinguish, in severe cases, if the condition is related to rotation due to facet dislocation or neck stiffness due to muscle spasm. When the spasm is on the side where the neck of the patient is directed to, it indicates facet dislocation, while the spasm is found in the contralateral sternocleidomastoid ${ }^{7}$ if related to neck stiffness. Nevertheless, the diagnosis can only be confirmed through computed tomography (CT) and magnetic resonance imaging (MRI). The cervical CT is usually used to evaluate the bones structure and classify the AARS. On the flipside, the MRI is more convenient to evaluate the ligaments structure, especially in cases where C1-C2 instability is presented.

Fielding and Hawkins, in the 1970s, in a series of cases consisting of 17 pediatric and adult patients aged 7 to 68 years old (mean 20.6 years old) who presented with irreducible AARS, classified the AARS in 4 types according to the injury level (-Fig. 3 ). In type I, a simple rotatory 

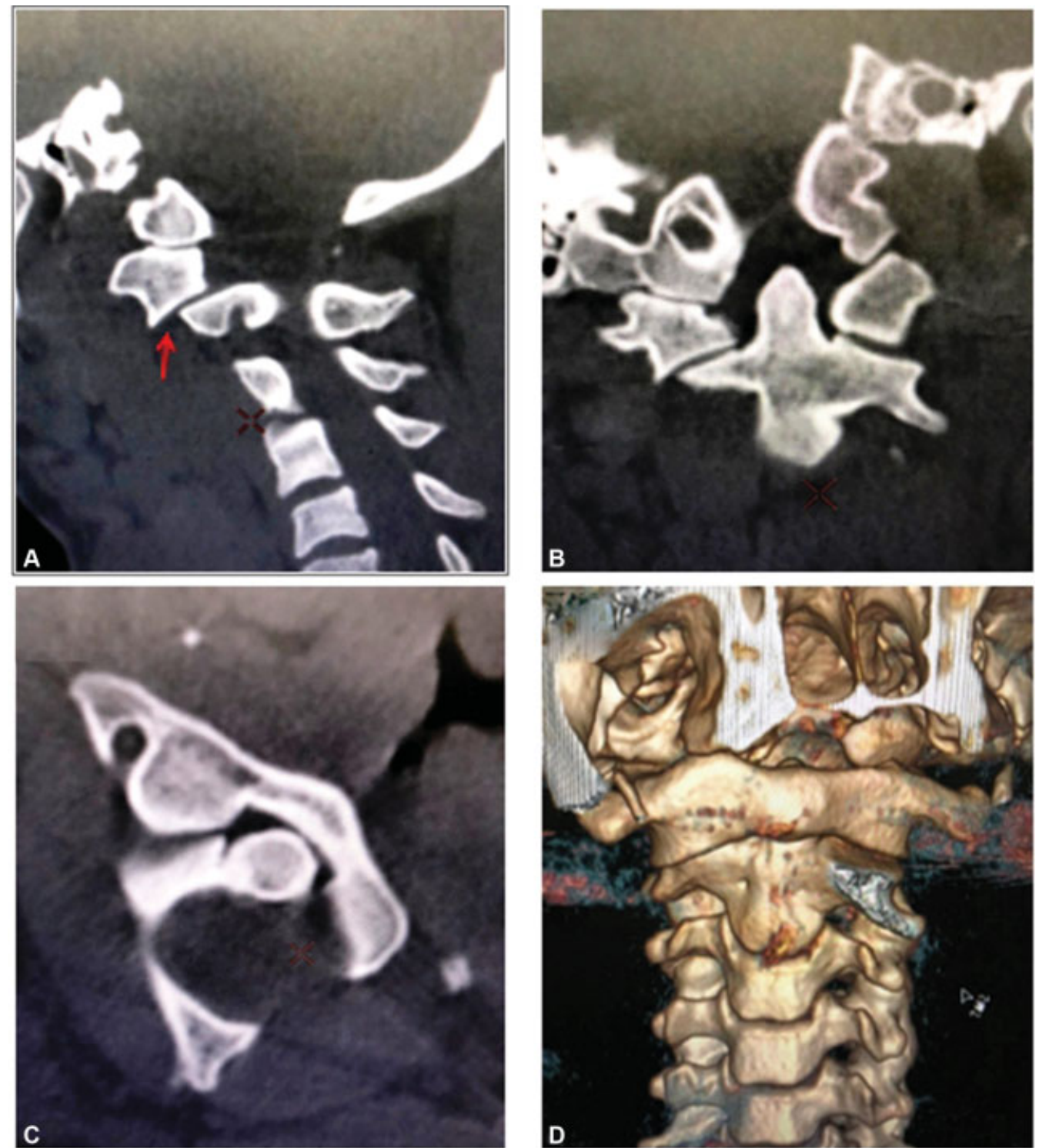

Fig. 1 Computed tomography before reduction: (A) Right C1-C2 injured articulation (check the arrow); (B) Coronal cut; (C) Axial cut with right C1-C2 rotatory luxation; (D) Tridimensional reconstruction showing the C1 lateral mass luxation on the right in relation to $C 2$.

dislocation can be observed, $\leq 3 \mathrm{~mm}$, with no anterior dislocation, presenting an intact transverse ligament. In type II, the anterior rotatory dislocation is between 3 and $5 \mathrm{~mm}$, the transverse ligament is injured, and the intact articulations play a pivotal role. Meanwhile, in type III, the anterior rotatory dislocation is $>5 \mathrm{~mm}$ with both lateral atlantoaxial articulations anteriorly subluxated, with the transversal ligament and the facet capsules injured. Finally, in type IV, a posterior subluxation of both lateral atlantoaxial articulations occurs, there is malfunctioning of the odontoid process and severe instability. ${ }^{8}$

The AARS etiology presents itself differently according to the age range. In pediatric patients, a connection with ligament laxity can be observed, anatomic abnormalities, Down syndrome, rheumatoid arthritis, infection or upper respiratory tract trauma resulting in Grisel syndrome. On the other side, in adult patients, high-energy traumas and injuries are the main causes. ${ }^{9}$
Many strategies to be used on the treatment of these superior cervical spine injuries are available: conservative treatment, reductions through plaster cast or surgery. Independently of the technical choice, the treatment must reduce the dislocation, protect the spinal canal, preserve the vertebral spine mobility as much as possible and, therefore, avoid permanent after-effects. In this way, the treatment choice depends on many criteria, such as the local stability of the injury, the transversal ligament integrity and the $\mathrm{C} 1$ posterior bow. ${ }^{10}$

The reducible AARS are usually of the incomplete type, when one of the $\mathrm{C} 1$ facet parts keeps contact with the $\mathrm{C} 2$ facet. Complete rotations can be reducible under traction, but this is a much lower possibility. Fielding and Hawkins suggested that the reduction during the severe phase is probably complicated due to the capsular and synovial tissue edema and the related muscle spasm. If the abnormal position persists due to a reduction attempt failure, a ligament 

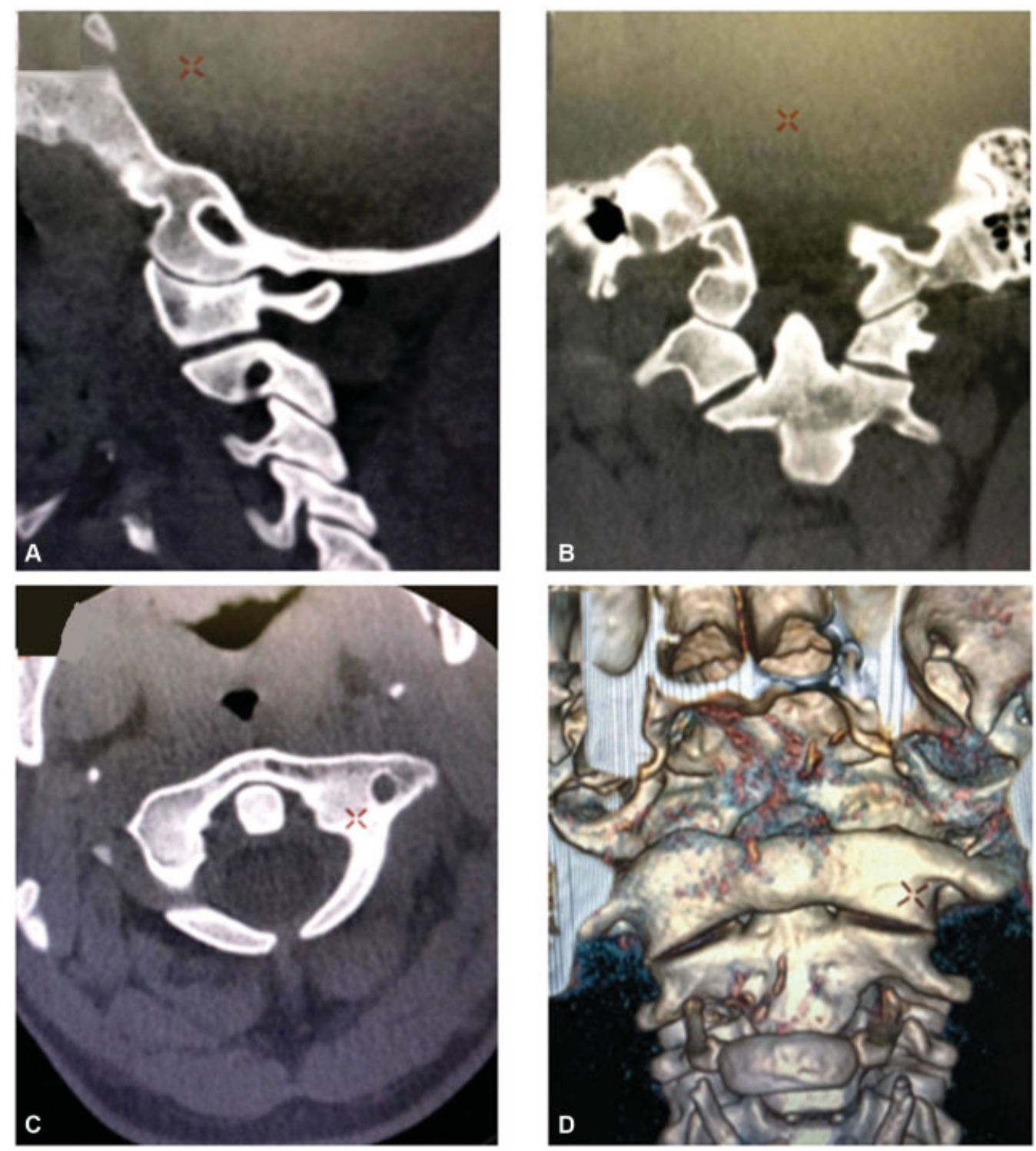

Fig. 2 Computed tomography after reduction: (A) Right C1-C2 articulation; (B) Coronal cut; (C) Axial cut; (D) Tridimensional reconstruction of the reduced $\mathrm{C} 1-\mathrm{C} 2$ articulation.

and a capsule contracture are developed, which cause the "fixation" in the dislocated position. ${ }^{7}$

The surgical treatment is indicated for cases in which the subluxation cannot be reduced or for cases when it recurs even after reduction.

The usual fusion is from $\mathrm{C} 1$ and $\mathrm{C} 2$, unless the patient presents other fractures or conditions, and can be conducted even if the rotation between C1 and C2 is not completely reduced.

In irreducible cases, a transoral atlantoaxial complex release $\mathrm{e}^{11,12}$ accessed through the extreme lateral of the neck, ${ }^{13}$ or a direct manipulation of the articulation through the posterior part of the neck, ${ }^{7}$ followed or not by cervical serial traction, can be conducted in the first step and, in the second step, the posterior fusion of $\mathrm{C} 1$ and $\mathrm{C}^{14}$ can be performed.

If treated within the first months, the subluxation can usually be reduced with soft traction and/or cervical manipulation. If the condition has been present for over a month, the traction treatment will have less chances of success. The neck active rotation from the left to the right is stimulated at the moment of the traction. If it is reducible, the traction immobilization is kept for $\sim 3$ months, with a time variation between 6 and 12 weeks. $^{14}$ In our case, despite the age of the patient, a successful nonoperative management was achieved.

The advantages of using the nonoperative treatment are fast subluxation correction, shorter hospitalization and recovery time, absence of surgical procedure, intraoperative injuries and postoperative risks. Overall, atlantoaxial injuries are rare and the treatment is still a challenge. It denotes the importance of an early diagnosis with a proper choice of treatment to be instituted, aiming to a better recovery process and a lower risk of neurological injuries.

\section{Conclusion}

In summation, AARS in adults is a rare condition and, in the majority of times, it is related to high-energy traumas, as was the case presented above. The best treatment to be considered 

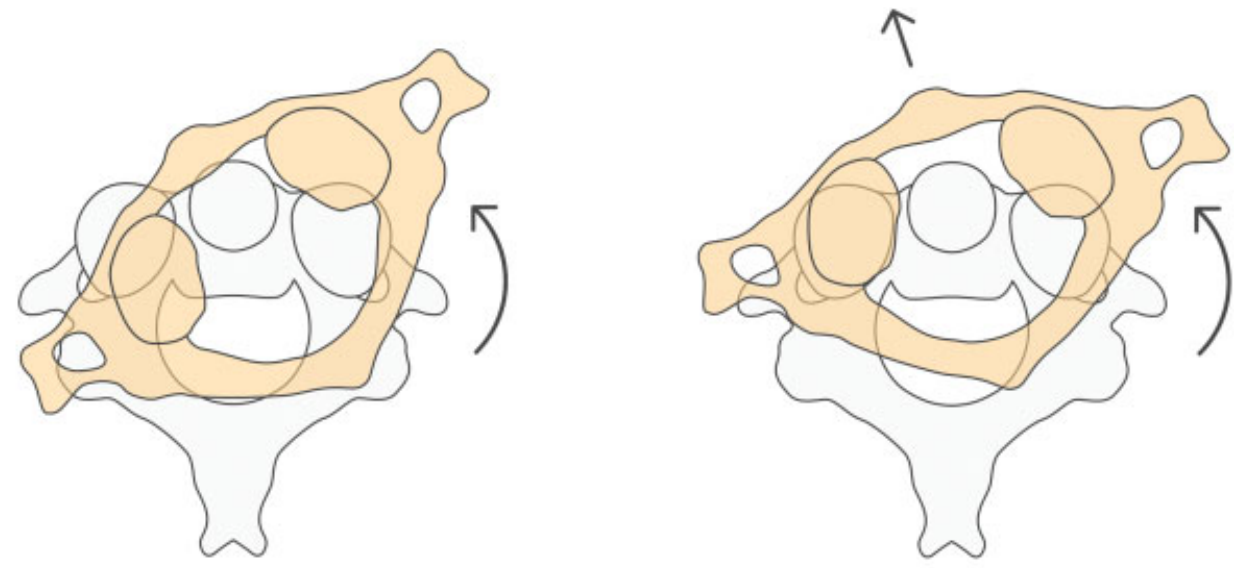

A

B
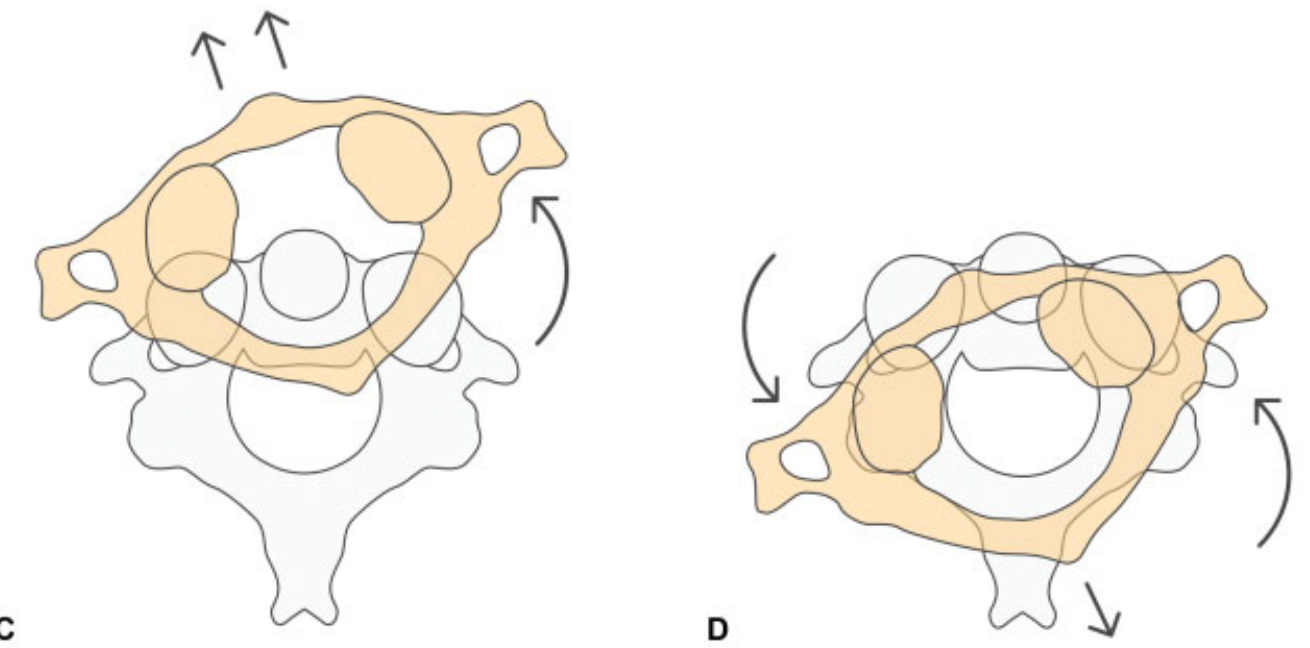

Fig. 3 Fielding and Hawkins classification: (A) Type I; (B) Type II; (C) Type III; (D) Type IV.

in this case is the conservative one, taking the early diagnosis and strong power of solvability into account. An early diagnosis is a requirement of extreme importance, due to the fact that a nonsurgical subluxation reduction can be achieved through it, which guarantees a higher level of comfort for the patient and a faster recovery process, also decreasing the complication rates related to late diagnosis.

\section{Patient's Consent}

The patient has agreed to the disclosure of her case, as well as of the exam images presented in this document, through a written agreement term.

\section{Conflict of Interests}

The authors have no conflict of interests to declare.

\section{References}

1 Riascos R, Bonfante E, Cotes C, Guirguis M, Hakimelahi R, West C. Imaging of atlanto-occipital and atlantoaxial traumatic injuries: what the radiologist needs to know. Radiographics 2015;35(07): 2121-2134
2 Tarantino R, Donnarumma P, Marotta N, et al. Atlanto axial rotatory dislocation in adults: a rare complication of an epileptic seizure-case report. Neurol Med Chir (Tokyo) 2014;54(05): 413-416

3 Barimani B, Fairag R, Abduljabbar F, et al. A missed traumatic atlanto-axial rotatory subluxation in an adult patient: case report. Open Access Emerg Med 2019;11:39-42

4 Eghbal K, Rakhsha A, Saffarrian A, Rahmanian A, Abdollahpour HR, Ghaffarpasand F. Surgical Management of Adult Traumatic Atlantoaxial Rotatory Subluxation with Unilateral Locked Facet; Case Report and Literature Review. Bull Emerg Trauma 2018;6 (04):367-371

5 Meyer C, Eysel P, Stein G. Traumatic atlantoaxial and fracturerelated dislocation. BioMed Res Int 2019;2019:5297950

6 Goel A, Jain S, Shah A. Management of a case of neglected atlantoaxial rotatory dislocation. Neurol India 2017;65(05):1170-1173

7 Goel A. Torticollis and rotatory atlantoaxial dislocation: A clinical review. J Craniovertebr Junction Spine 2019;10(02):77-87

8 Fielding JW, Hawkins RJ. Atlanto-axial rotatory fixation. (Fixed rotatory subluxation of the atlanto-axial joint). J Bone Joint Surg Am 1977;59(01):37-44

9 Hawi N, Alfke D, Liodakis E, et al. Case report of a traumatic atlantoaxial rotatory subluxation with bilateral locked cervical facets: management, treatment, and outcome. Case Rep Orthop 2016;2016:7308653 
10 Peyriere H, Graillon T, Pesenti S, Tropiano P, Blondel B, Fuentes S. Surgical management of post-traumatic atlantoaxial rotatory fixation due to C2 facet fracture: 5 clinical cases. Orthop Traumatol Surg Res 2017;103(01):67-70

11 Schmidek HH, Smith DA, Sofferman RA, Gomes FB. Transoral unilateral facetectomy in the management of unilateral anterior rotatory atlantoaxial fracture/dislocation: a case report. Neurosurgery 1986;18(05):645-652

12 Goto S, Mochizuki M, Kita T, Murakami M, Nishigaki H, Moriya H. Transoral joint release of the dislocated atlantoaxial joints com- bined with posterior reduction and fusion for a late infantile atlantoaxial rotatory fixation. A case report. Spine 1998;23(13): $1485-1489$

13 Crockard HA, Rogers MA. Open reduction of traumatic atlantoaxial rotatory dislocation with use of the extreme lateral approach. A report of two cases. J Bone Joint Surg Am 1996;78(03): 431-436

14 Greenberg MS. Handbook of Neurosurgery. $8^{\mathrm{a}}$ ed. New York: Thieme; 2016 